\title{
Differential immunomodulatory effects by Tripterygium wilfordii Hook f-derived refined extract PG27 and its purified component PG490 (triptolide) in human peripheral blood T cells: potential therapeutics for arthritis and possible mechanisms explaining in part Chinese herbal theory "Junn-Chenn-Zuou-SS"
}

Ling-Jun $\mathrm{Ho}^{1,2}$, Wen-Liang Chang ${ }^{3}$, Ann Chen ${ }^{4}$, Ping Chao ${ }^{5}$ and Jenn-Haung Lai ${ }^{6^{*}}$

\begin{abstract}
Background: For thousands of years, it remains unclear why Chinese prefer complex herbal remedy and seldom try to purify it. One of the reasons is that they believe Chinese herbs compared to Western drugs are relatively less toxic and better tolerated. The so called "Junn-Chenn-Zuou-SS" theory illustrates a concept of coordinated effects from a combination of different Chinese herbs. PG27, a refined extract from a well-known Chinese antirheumatic herb Tripterygium wilfordii Hook $\mathrm{f}(\mathrm{TwHf})$, is effective in attenuating transplantation rejection and extending survival of cardiac xenografts.
\end{abstract}

Methods: Experiments were conducted in human primary $T$ lymphocytes isolated from buffy coat. The activities of the inhibitor of kappaB alpha kinase-inhibitor of kappaB alpha-nuclear factor kappaB (IKK-IKBa-NF-kB) and mitogen activated protein kinase-activator protein-1 (MAPK-AP-1) signaling pathways were determined via electrophoretic mobility shift assays, immunoprecipitation kinase assays, Western blots, and transfection assays.

Results: We showed that PG27 inhibited IKKa-IKBa-NF-KB and MAPK-AP-1 signaling pathways; however, IKK $\beta$ activity was less susceptible to inhibition by PG27. In contrast, the purified component of TwHF, PG490 (triptolide), reduced both MAPK-AP-1 and IKK-IKBa-NF-KB signaling pathways, including both IKKa and IKK 3 , with similar potency. By means of high performance liquid chromatography analysis, it was estimated that PG490 constituted $1.27 \pm 0.06 \%$ of the total PG27 content. Further analysis demonstrated that compared to PG490 alone, PG27 that contained an equal amount of PG490 was less toxic and less immunosuppressive, suggesting the presence of cytoprotective ingredient(s) in the non-PG490 components of PG27.

(Continued on next page)

\footnotetext{
* Correspondence: laiandho@gmail.com

${ }^{6}$ Division of Allergy, Immunology and Rheumatology, Department of Internal Medicine, Chang Gung Memorial Hospital, Chang Gung University, Tao-Yuan, Taiwan, R. O. C

Full list of author information is available at the end of the article
}

\section{Biomed Central}

(c) 2013 Ho et al.; licensee BioMed Central Ltd. This is an open access article distributed under the terms of the Creative Commons Attribution License (http://creativecommons.org/licenses/by/2.0), which permits unrestricted use, distribution, and reproduction in any medium, provided the original work is properly cited. 
(Continued from previous page)

Conclusions: In addition to demonstrating the immunomodulatory capacity of PG27 as the potential therapeutics for arthritis and prevention of transplantation rejection, the differential regulatory effects and mechanisms by PG27 and PG490 further support in part a possibly-existing Chinese herbal theory "Junn-Chenn-Zuou-SS".

Keywords: Tripterygium wilfordii Hook f, Nuclear factor kappaB, I-kappaBalpha kinase-beta, PG27, PG490 (Triptolide), T Cells

\section{Background}

According to the concept of Chinese herbal therapy, the greatest therapeutic effects come from a combination of several ingredients; some of them are effective in treating diseases and some of them modulate the function of these active components through enhancing their efficacy, reducing their side effects, or manipulating their delivery into the target organs. The record about this concept called "Junn-Chenn-Zuou-SS" is first published in Shen Nong Ben Cao Jing, an earliest medical material dictionary composed at the era of Qin and Han dynasties. The theory "Junn-Chenn-Zuou-SS" has been generally adopted in Chinese medicine practice where "Junn" represents the active effective ingredient(s); "Chenn" is the adjunctive ingredient(s) enhancing the effectiveness of active ingredient (s); "Zuou" is the complementary ingredient(s) reducing the side effects of active effective ingredient(s) and "SS" is the ingredient(s) helpful in delivering the active effective ingredient(s) into the target organs. The "Junn-ChennZuou-SS" theory is presumably achieved by administering different herbs (called "Danfang" for each herb) with known functions together called a "Fufang" at a time. The concept of "Fufang" in fact has already been applied in medicine for a long time including the medications from Western societies. Typical examples include the treatments for rheumatoid arthritis (RA) [1] and HIV infection [2]. In these examples, a combination of several drugs preserving different inhibitory effects and mechanisms on specific molecules or pathways may work together and achieve synergistic effects. By doing this, the dosages of individual drugs may be greatly reduced to attenuate the potential toxic effects from each drug and yet the effects are synergistically enhanced. Nevertheless, there has been no scientific evidence showing that "Junn-Chenn-Zuou-SS" therapeutic theory may exist and work by different components in a single herb.

The most commonly used Chinese medicine for autoimmune disorders, such as RA, is Tripterygium wilfordii Hook f (TwHf; known as Thunder God Vine), which has potent immunosuppressive effects [3,4]. Currently, different TwHf extracts are prescribed to treat autoimmune disorders in mainland China. Aside from extensive clinical trials conducted in oriental populations, the double blinded studies in RA patients of Western populations also confirm its effectiveness $[5,6]$. In our previous work, we demonstrated that TwHf is an effective immunomodulatory drug, which acts by inhibiting T-cell activation and inducing T-cell apoptosis $[7,8]$. Although the usefulness of each ingredient of TwHf extracts has not been studied in detail, the major therapeutic effects of TwHf have been suggested to be from some of the ingredients such as PG490 (triptolide), tripdiolide, triptonide and triptophenolide [9-11].

Because the commonly prescribed TwHf preparations are considered to have toxicities, this greatly reduces the usefulness of this drug for clinical purposes. In order to minimize drug toxicity yet reserve drug efficacy, further purification of TwHf leads to the refined extract called PG27 that shows promising effects in prevention of bone marrow transplantation rejections [12]. Importantly, a combination of both PG27 and cyclosporine results in strong synergistic effects in extending the survival of hamster-to-rat cardiac xenograft model [13]. In this context, the TwHf purified product PG490 also preserves strong immunosuppressive effects $[14,15]$. In the light of the current therapeutic strategy for autoimmune disorders with a combination of several disease-modifying antirheumatic drugs to increase efficacy and to reduce adverse events [1], the exploration of effects and mechanisms of Chinese antirheumatic drugs should bring more alternatives for the therapy of autoimmune disorders.

The nuclear factor kappaB (NF-kB) family consists of Rel-domain-containing proteins that are crucial for the regulation of inflammation and immune responses [16,17]. In resting cells, these proteins are retained in the cytosol by a group of inhibitory proteins such as inhibitor of kappaB alpha $(\mathrm{I} \kappa \mathrm{B} \alpha)$. After activation, $\mathrm{I} \kappa \mathrm{B} \alpha$ is phosphorylated by IKB $\alpha$ kinases (IKKs) such as IKK $\alpha$ and IKK $\beta$, and undergoes ubiquitination and subsequent proteosome-mediated degradation [18]. This leads to the nuclear translocation of NF- $\mathrm{kB}$ from the cytosol and induces the activation of a variety of genes, leading to diseases such as RA [19]. Similar to NF- $\mathrm{kB}$, the activating protein-1 (AP-1) transcription factors, which consist of Jun and Fos family proteins, extensively participate in regulating cell proliferation, transformation and death, and serve as good therapeutic targets for the control of inflammation [20].

In this report, we investigated the effects and mechanisms of PG27-mediated immunomodulation in primary T cells. We observed that PG27 had differential immunosuppressive potency for IKK $\alpha$ and IKK $\beta$, a phenomenon 
not observed for the purified compound PG490. In addition, PG27 that contained an equivalent amount of PG490 was less toxic than PG490 alone. These observations explain in part a possible mechanism of "JunnChenn-Zuou-SS" theory and provide evidence suggesting that PG27 may be assessed for potential use as a diseasemodifying antirheumatic drug for autoimmune disorders like RA.

\section{Materials and methods}

\section{Preparation of PG27 and PG490}

PG27 powder was prepared by Pharmagenesis (La Jolla, California) and was kindly provided by PhytoHealth, Inc, Taipei, Taiwan. PG490 was purchased from Sigma-Aldrich Chemical Company (St. Louis, MO). Both drugs were dissolved in DMSO to generate $100 \mathrm{mg} / \mathrm{mL}$ (PG27) or $100 \mathrm{ng} / \mathrm{mL}$ (PG490) stock solutions. For experiments, the required concentrations of each drug were made by dilution of the concentrated stock solution with culture medium, which contained RPMI 1640 medium supplemented with $10 \%$ fetal bovine serum, $2 \mathrm{mM}$ glutamine, and $1,000 \mathrm{U} / \mathrm{mL}$ penicillin-streptomycin (Gibco-BRL, Gaithersberg, MD).

\section{Preparation of peripheral blood T cells}

The use of buffy coat purchased from the blood bank (Taipei, Taiwan) was approved by the Institutional Review Board, Tri-Service General Hospital, through a fast review tract. Human peripheral blood T cells were purified from whole blood via negative selection, according to our previous report [8]. Briefly, buffy coat was mixed with Ficoll-Hypaque, and the layer of mononuclear cells was collected after centrifugation. After lysis of red blood cells, the peripheral blood mononuclear cells were incubated with antibodies (Abs), including L243 (anti-DR; American Type Culture Collection [ATCC], Rockville, MD), OKM1 (anti-CD11b; ATCC), and LM2 (anti-Mac1; ATCC) for $30 \mathrm{~min}$ at $4^{\circ} \mathrm{C}$. The cells were washed with medium containing $10 \%$ fetal bovine serum and incubated with magnetic beads conjugated to goat anti-mouse IgG ( R \& D, Minneapolis, MN). The antibodystained cells were then removed with a magnet. Following a repeat of the above procedures, $\mathrm{T}$ cells were obtained with a purity of more than $98 \%$, as determined by the percentage of $\mathrm{CD}^{+}$cells in flow cytometry (Beckton Dickinson, Mountain View, CA).

\section{Cell stimulation, cytokine determination, and cell survival measurement}

To activate $\mathrm{T}$ cells, the following stimuli were used: phorbol 12-myristate 13-acetate (PMA; Sigma) at $10 \mathrm{ng} / \mathrm{mL}$, ionomycin (Sigma) at $1 \mu \mathrm{M}$, immobilized monoclonal antibody (mAb) anti-CD3 (OKT3; ATCC) at $10 \mu \mathrm{g} / \mathrm{mL}$, soluble anti-CD28 mAb (Beckton Dickinson) at $1 \mu \mathrm{g} / \mathrm{mL}$, and TNF- $\alpha$ at $10 \mathrm{ng} / \mathrm{mL}$. The cells were incubated with the various stimuli, and the cell pellets or supernatants were collected for analysis. The determination of cytokine concentrations was performed via ELISA as described previously [21]. $\mathrm{IC}_{50}$ was the concentration of drug (PG27 or PG490) that inhibited half the cytokine production from different stimuli-activated $\mathrm{T}$ cells and was calculated by linear regression using Microsoft Excel. Cell viability was measured by either the trypan blue exclusion assay or the MTT (3-[4,5-Dimethylthiazol-2-yl]-2,5-diphenyl-tetrazolium bromide) colorimetric assay, as described in our previous report [8]. Similarly, the 50\% lethal concentrations ( $\mathrm{LC}_{50}$ ) of PG27 and PG490 were calculated.

\section{Preparation of cytoplasmic and nuclear extracts}

Cytoplasmic and nuclear extracts were prepared according to our published work [21]. Briefly, treated cells were incubated at $4^{\circ} \mathrm{C}$ in $50 \mu \mathrm{L}$ of buffer A (10 mM HEPES, $\mathrm{pH}$ 7.9, $10 \mathrm{mM} \mathrm{KCl}, 1.5 \mathrm{mM} \mathrm{MgCl}_{2}, 1 \mathrm{mM}$ DTT, $1 \mathrm{mM}$ PMSF, $3.3 \mu \mathrm{g} / \mathrm{mL}$ aprotinin) for $15 \mathrm{~min}$, with occasional gentle vortexing. The swollen cells were centrifuged at $15,000 \mathrm{rpm}$ for $3 \mathrm{~min}$. After removal of the supernatants (cytoplasmic extracts), the pelleted nuclei were washed with $50 \mu \mathrm{L}$ of buffer $\mathrm{A}$, and subsequently, the cell pellets were resuspended in $30 \mu \mathrm{L}$ of buffer $\mathrm{C}$ (20 mM HEPES, $\mathrm{pH}$ 7.9, $420 \mathrm{mM} \mathrm{NaCl}, 1.5 \mathrm{mM} \mathrm{MgCl}_{2}, 0.2 \mathrm{mM}$ EDTA, 25\% glycerol, $1 \mathrm{mM}$ DTT, $0.5 \mathrm{mM}$ PMSF, $3.3 \mu \mathrm{g} / \mathrm{mL}$ aprotinin) and incubated at $4^{\circ} \mathrm{C}$ for $30 \mathrm{~min}$, with occasional vigorous vortexing. The mixtures were then centrifuged at 15,000 rpm for $20 \mathrm{~min}$, and the supernatants were used as nuclear extracts.

\section{Electrophoretic mobility shift assays (EMSAs)}

EMSAs were performed as detailed in our previous report [21]. Oligonucleotides containing the NF-kB-binding site (5'-AGT TGA GGG GAC TTT CCC AGG C-3'), the AP-1-binding site (5'-CGC TTG ATG AGT CAG CCG GAA-3'), and the Oct-1-binding site (5'-TGT CGA ATG CAA ATC ACT AGA A-3') were purchased and used as DNA probes (Promega, Madison, WI). The DNA probes were radio-labeled with $\left[\gamma_{-}{ }^{32} \mathrm{P}\right] \mathrm{ATP}$ using T4 kinase, according to the manufacturer's instructions (Promega). For the binding reactions, the radio-labeled probes were incubated with $5 \mu \mathrm{g}$ of nuclear extracts. The binding buffer contained $10 \mathrm{mM}$ Tris- $\mathrm{HCl}, \mathrm{pH} 7.5,50 \mathrm{mM} \mathrm{NaCl}$, $0.5 \mathrm{mM}$ EDTA, $1 \mathrm{mM}$ DTT, $1 \mathrm{mM} \mathrm{MgCl}_{2}$, 4\% glycerol, and $2 \mu \mathrm{g}$ poly $(\mathrm{dI}-\mathrm{dC})$. The reaction mixtures were incubated at room temperature for $20 \mathrm{~min}$ prior to the binding reaction. For supershift assays, different mAbs were preincubated with nuclear extracts for $30 \mathrm{~min}$ before the addition of the radiolabeled probes. The final reaction mixtures were analyzed in 6\% non-denaturing polyacrylamide gels with $0.25 \times$ Tris-borate/EDTA as an electrophoresis buffer. 


\section{Western blotting}

ECL Western blotting (Amersham, Arlington Heights, IL) was performed as described previously [8]. Briefly, equal amounts of whole cell lysates and cytoplasmic or nuclear extracts were analyzed by $10 \%$ SDS-PAGE and transferred to a nitrocellulose filter. For immunoblotting, the nitrocellulose filter was incubated with Tris-buffered saline containing 5\% nonfat milk (milk buffer) for $2 \mathrm{~h}$, and then blotted with antisera against IKB $\alpha$, IKK $\alpha$, IKK $\beta$ (Santa Cruz Biotechnology), or $\beta$-actin overnight at $4^{\circ} \mathrm{C}$. After washing twice with milk buffer, the filter was incubated with donkey anti-mouse IgG conjugated to horseradish peroxidase at a concentration of 1:5,000 for $30 \mathrm{~min}$. The filter was then incubated with the substrate and exposed to X-ray film.

\section{Immunoprecipitation kinase assay}

The immunoprecipitation kinase assay was described in detail in our previous report [21]. The GST-IkB $\alpha$ fusion protein was used as a substrate for IKK $\alpha$ and IKK $\beta$. The JNK substrate, a GST-c-Jun fusion protein, was a kind gift from Dr. S.-F. Yang (Academia Sinica, Taiwan). Myelin basic protein (MBP), which was used as a substrate for both ERK and p38, was purchased from Sigma. The Abs used for the kinase assays were purchased from Cell Signaling (Beverly, MA; for anti-JNK and anti-p38 polyclonal Abs) and Santa Cruz Biotechnology (for anti-ERK, antiIKK $\alpha$ and anti-IKK $\beta$ polyclonal Abs). To perform the immunoprecipitation kinase assay, 50-100 $\mu \mathrm{g}$ of whole cell extract was incubated with $5 \mu \mathrm{L}$ of specific Abs in an incubation buffer (25 mM HEPES, pH 7.7, $300 \mathrm{mM} \mathrm{NaCl}$, $1.5 \mathrm{mM} \mathrm{MgCl}_{2}, 0.2 \mathrm{mM}$ EDTA, $0.1 \%$ Triton-X-100, $20 \mathrm{mM} \beta$-glycerophosphate, $0.1 \mathrm{mM} \mathrm{Na} \mathrm{VO}_{4}, 2 \mu \mathrm{M}$ leupeptin, $400 \mu \mathrm{M}$ PMSF) overnight. The mixture was then immunoprecipitated by the addition of protein A beads and rotated at $4^{\circ} \mathrm{C}$ for $2 \mathrm{~h}$. After extensive washing, (twice with a HEPES washing buffer [20 mM HEPES, pH 7.7, $50 \mathrm{mM} \mathrm{NaCl}, 2.5 \mathrm{mM} \mathrm{MgCl}_{2}, 0.1 \mathrm{mM}$ EDTA, 0.05\% Triton X-100]; twice with an $\mathrm{LiCl}$ washing buffer [500 mM LiCl, $100 \mathrm{mM}$ Tris, $\mathrm{pH}$ 7.6, 0.1\% Triton X-100, $1 \mathrm{mM}$ DTT]; and twice with a kinase buffer [20 mM MOPS, $\mathrm{pH}$ 7.2, $2 \mathrm{mM}$ EDTA, $10 \mathrm{mM} \mathrm{MgCl}_{2}, 0.1 \%$ Triton X-100 and $1 \mathrm{mM}$ DTT], the beads were resuspended in $40 \mu \mathrm{L}$ of kinase buffer, along with cold ATP $(30 \mu \mathrm{M})$ and $10 \mu \mathrm{Ci}$ of $\left[\gamma^{-}{ }^{32} \mathrm{P}\right] \mathrm{ATP}$. The mixture was incubated at $30^{\circ} \mathrm{C}$ with occasional gentle mixing for $30 \mathrm{~min}$. The reaction was then terminated by resuspending the samples in a 1\% SDS solubilizing buffer and boiling for $5 \mathrm{~min}$. The samples were then analyzed by SDS-PAGE.

\section{Transfection assay in purified human peripheral blood $\mathrm{T}$ cells}

The transfection assay was performed by electroporation with an Amaxa Nucleofector apparatus, according to the manufacturer's instructions (Amaxa, Cologne, Germany). In brief, primary $\mathrm{T}$ cells were mixed with $5 \mu \mathrm{g}$ of the reporter plasmid pNF-kB-luciferase (Luc) or pAP-1-Luc (Stratagene, La Jolla, CA) in $100 \mu \mathrm{L}$ of the provided electroporation buffer. After electroporation, the cells were transferred to $2 \mathrm{~mL}$ of pre-warmed RPMI medium. After transfection for $48 \mathrm{~h}$, the cells were aliquoted equally for testing the individual conditions described in the figure legends. For treatment, the drugs were added $2 \mathrm{~h}$ before the addition of stimuli. After stimulation with TNF- $\alpha$ for $18 \mathrm{~h}$, the cell pellets were collected, total cell lysates were prepared, and the luciferase activity, after normalization to the total protein amounts, was determined according to the manufacturer's instructions (Promega).

\section{Analysis of the PG490 content in PG27 by HPLC}

Both PG490 (1.6 mg) and PG27 (2.4 mg) were dissolved in DMSO $(1.0 \mathrm{~mL})$ to generate stock solutions. PG490 was spiked into the mobile phase to create a series of standards consisting of $0.0125,0.025,0.05,0.1,0.2,0.4$, 0.8 , and $1.6 \mathrm{mg} / \mathrm{mL}$ concentrations. High Performance Liquid Chromatography (HPLC) was performed on an Agilent Model 1100 Quat pump system equipped with an Agilent 1100 VWD Detector and an Agilent 1100 ALS auto-injector. The detector was set to $218 \mathrm{~nm}$. A reversed phase column (Cosmosil 5C18-AR-II, $25 \mathrm{~cm} \times$ $4.6 \mathrm{~mm}$ I.D.) was applied. The mobile phase was $45 \%$ $\mathrm{MeOH} / 55 \% \mathrm{H}_{2} \mathrm{O}$ eluted at a flow rate of $0.8 \mathrm{~mL} / \mathrm{min}$. The injection volume was $20 \mu \mathrm{L}$ for each sample.

\section{Statistics}

The results were expressed as means \pm standard deviations. One-way ANOVA analysis was used to evaluate the differences, which were considered to be statistically significant at a $P$ value of $<0.05$.

\section{Results \\ PG27 inhibited IL-2 production from activated T cells}

To determine whether PG27 exhibited immunosuppressive effects that were as potent as the crude TwHf extract, purified $T$ cells were activated with various stimuli in the presence or absence of PG27, and IL-2 concentrations were determined by ELISA (Figure 1). PG27 inhibited IL-2 production induced by PMA + ionomycin (Figure 1A) or CD3/ CD28 (Figure 1B) in a concentration-dependent manner. There was no detectable cytotoxicity, in the presence or absence of stimulus, resulting from the tested concentrations of PG27 (Figure 1C and data not shown).

\section{PG27 inhibited NF-KB and AP-1 activation induced by various stimuli}

We next examined the potential effects of PG27 on the activation of NF-kB and AP-1. After the treatment with different stimuli in the presence or absence of various 
A
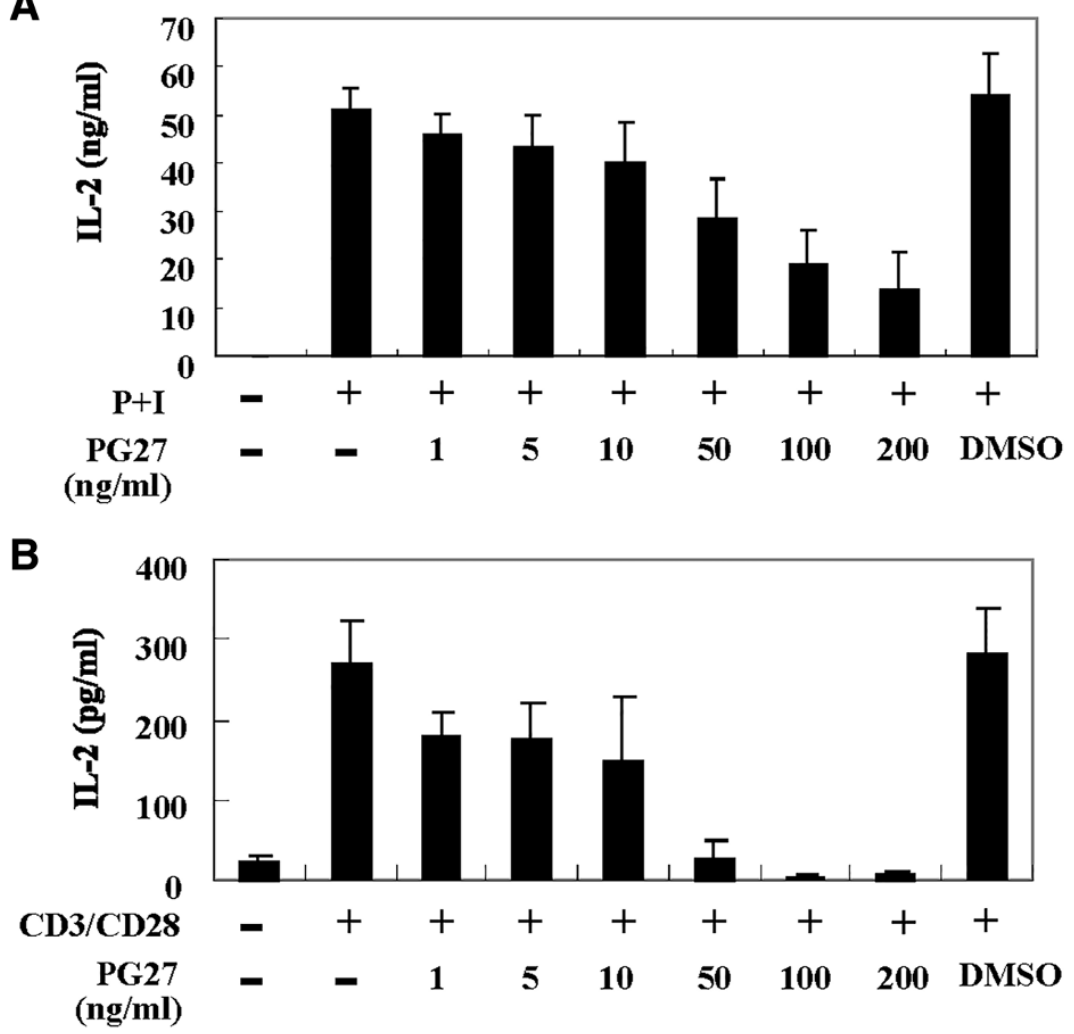

C

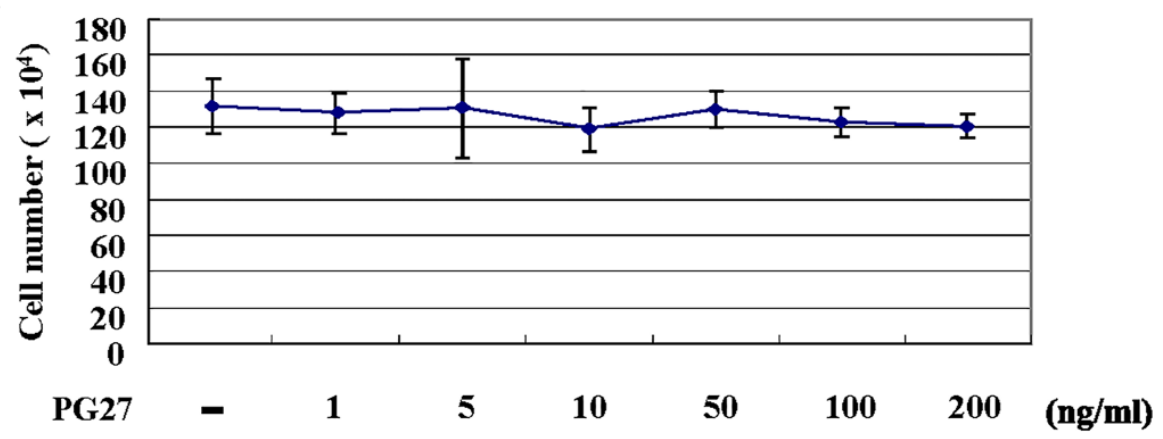

Figure 1 PG27 inhibited IL-2 production from activated T cells in a concentration-dependent manner. Human peripheral blood T cells at a concentration of $1 \times 10^{6} / \mathrm{mL}$ were pretreated with various concentrations of PG27 for $2 \mathrm{~h}$ and then stimulated with PMA + ionomycin (shown as $\mathrm{P}+\mathrm{I}$ ) (A) or CD3/CD28 (B) for $24 \mathrm{~h}$. The supernatants were collected for the determination of IL-2 concentrations. In parallel, cell survival in the various conditions was determined by trypan blue exclusion assays (C). The results shown are from independent experiments. Each experiment was performed in triplicate using T cells from at least 3 different donors.

concentrations of PG27, T cells were collected and nuclear extracts were prepared and analyzed by EMSA. As shown in Figure 2, PG27 suppressed PMA + ionomycin-induced (Figure 2A) and CD3/CD28-induced (Figure 2B) NF-kB and AP-1 DNA-binding activities. Considering the important role of TNF- $\alpha$ in inflammatory response, we also examined the effects of PG27 on TNF- $\alpha$-stimulated T cells. Consistent with the experimental results for the previous stimuli, PG27 efficiently reduced the TNF- $\alpha$-induced NF$\mathrm{\kappa B}$ and AP-1 DNA-binding activities (Figure 2C). In contrast, PG27 did not affect the DNA-binding activity of the negative control Oct-1 (Figure 2C). Furthermore, the highest concentration of the solvent DMSO used to dissolve PG27 did not show any inhibitory effect on NF- $\mathrm{KB}$ or AP-1 DNA-binding activity (data not shown). Using EMSA supershift analysis, performed in the presence of anti-p65 or anti-p50 mAbs, we further demonstrated that the transcription factors induced by TNF- $\alpha$ and PMA + ionomycin that bound the radiolabeled $\mathrm{kB}$ oligonucleotide probes consisted of at least p65 and p50 (Figure 2D). These results are consistent with the observations demonstrated in our previous report examining nuclear extracts 


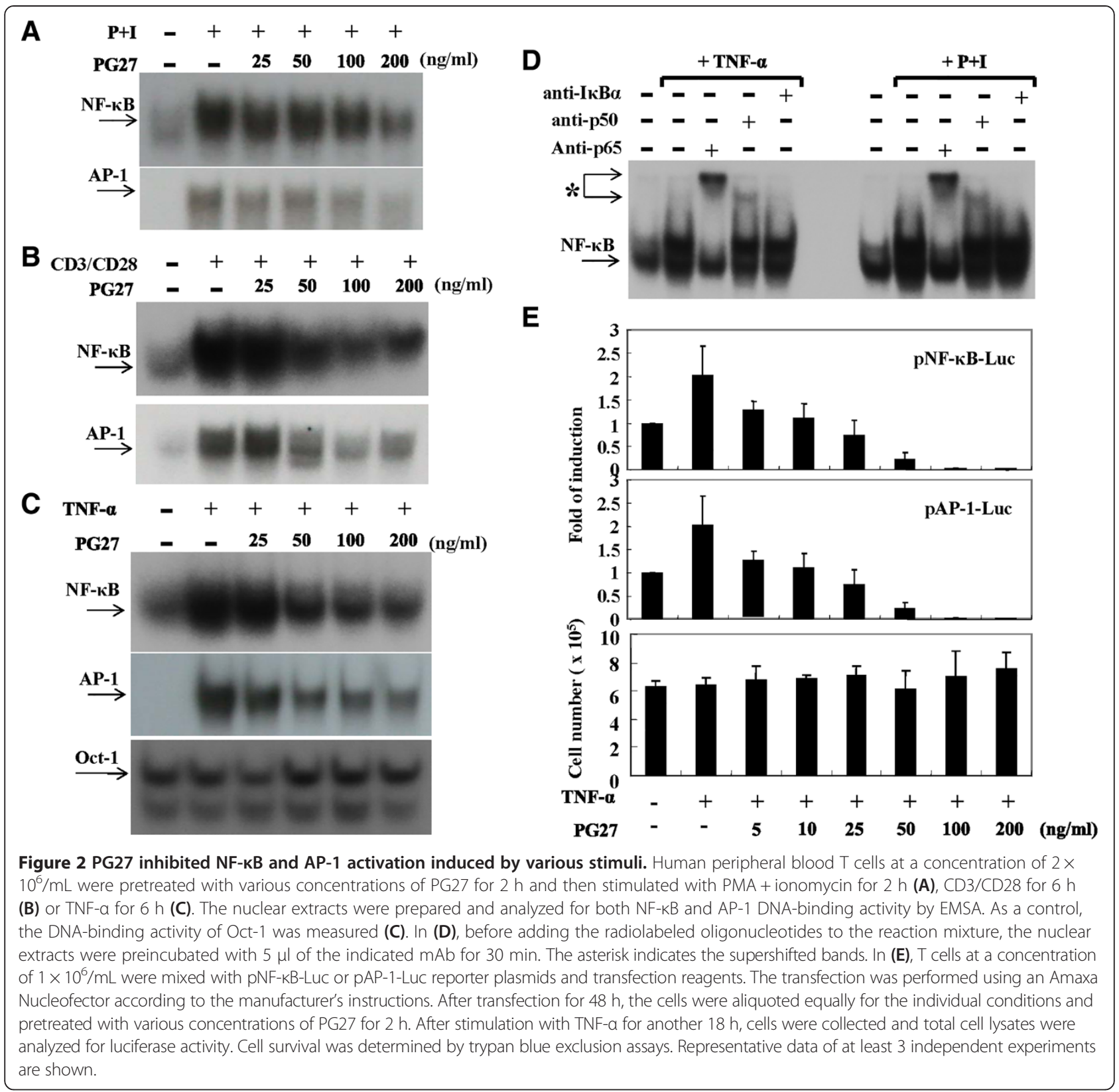

from CD3/CD28-stimulated $\mathrm{T}$ cells [21]. To assess whether PG27 inhibited the transcription of genes containing binding sites for NF- $\mathrm{kB}$ and AP-1, we transiently transfected NF- $\mathrm{kB}$ - or AP-1-luciferase reporter constructs into purified human peripheral blood $\mathrm{T}$ cells. Forty-eight hours after transfection, $\mathrm{T}$ cells were aliquoted equally for the treatment with various concentrations of PG27 and then stimulated with TNF- $\alpha$ as indicated (Figure 2E). The total cell lysates were prepared and the luciferase activities were determined. The data showed that PG27 effectively suppressed the transcriptional activities of both NF- $\mathrm{kB}$ and AP-1 induced by TNF- $\alpha$ (Figure 2E). Side-by-side examinations of cell viability revealed no significant cytotoxicity of PG27 in all conditions tested (Figure 2E).

\section{Effects of PG27 on IKBa degradation and IKK activity}

The upstream signaling molecules that control the activation of NF-kB were examined. T cells were treated with TNF- $\alpha$ for 15,30 , or $60 \mathrm{~min}$ in the presence or absence of PG27, and then cytoplasmic extracts were prepared to determine $I \kappa B \alpha$ levels by Western blotting. As shown in Figure $3 \mathrm{~A}$, the cytosolic levels of $\mathrm{I} \kappa \mathrm{B} \alpha$ decreased after TNF- $\alpha$ stimulation for $15 \mathrm{~min}$; however, the pre-treatment with PG27 maintained IkB $\alpha$ levels close to the basal level. When nuclear extracts were examined for NF- $\mathrm{kB}$ DNA- 


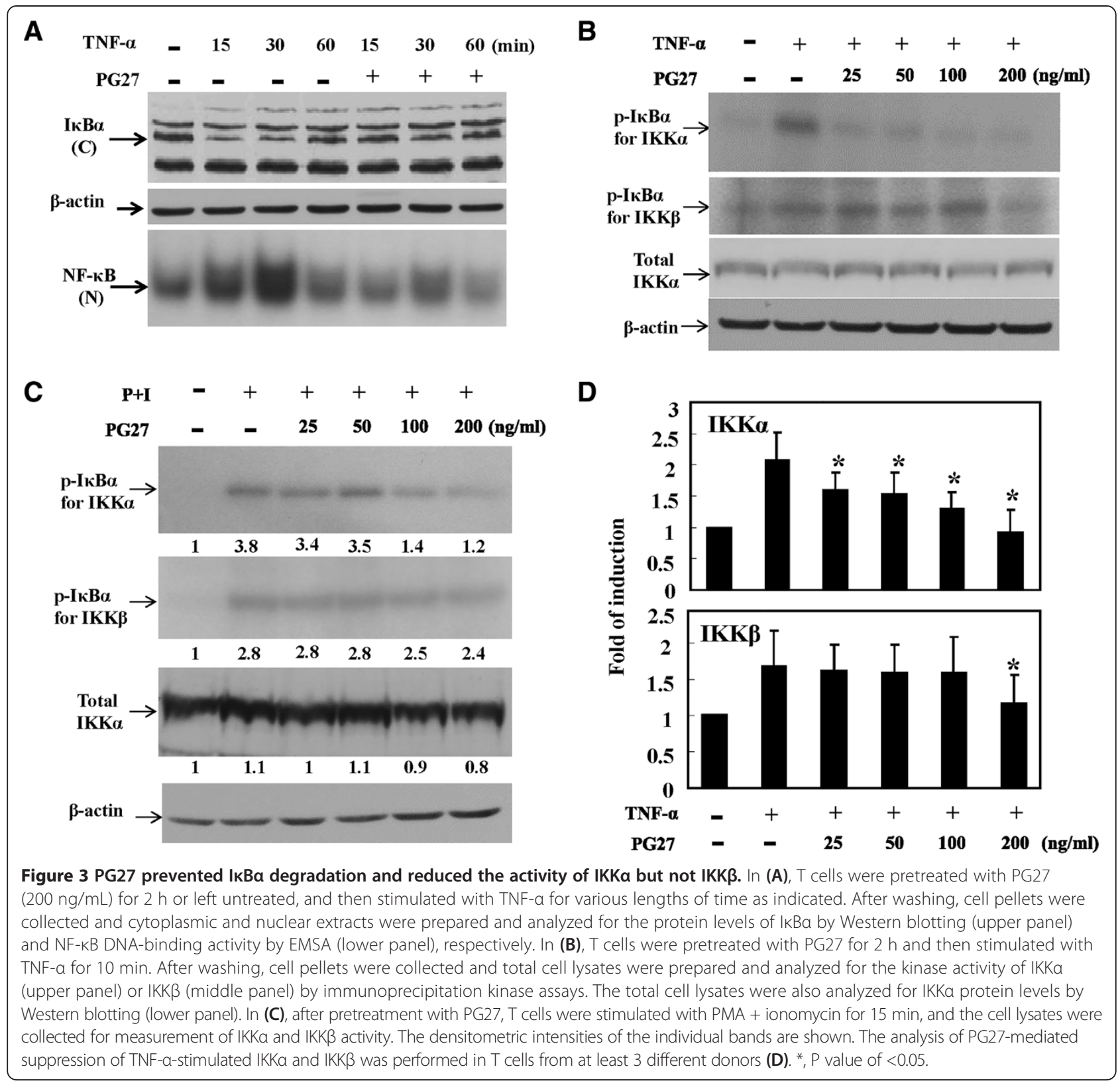

binding activity, similar levels of suppression by PG27 were observed (Figure 3A). Considering that the regulation of $\mathrm{I} \kappa \mathrm{B} \alpha$ protein levels depends on the activity of IKKs, which phosphorylate I $\mathrm{BB} \alpha$ leading to its ubiquitination and degradation, we next wanted to determine whether PG27 could suppress IKK activity. To this end, immunoprecipitation kinase assays were performed with GST-IKB $\alpha$ as a substrate for both IKK $\alpha$ and IKK $\beta$. As shown in Figure 3B, PG27 at a wide range of concentrations suppressed TNF- $\alpha$-induced IKK $\alpha$ activity. In contrast, TNF- $\alpha$-induced IKK $\beta$ activity was unexpectedly resistant to PG27 treatment; suppression was observed only mildly under the highest concentration of PG27 (Figure 3B). The differential suppression of IKK $\alpha$ and IKK $\beta$ activity by PG27 was not due to unequal loading of total protein, because the basal IKK $\alpha$ and $\beta$-actin levels appeared to be very similar for each sample (Figure $3 \mathrm{~B}$ ). To determine whether the differential suppression of IKK $\alpha$ and IKK $\beta$ by PG27 was specifically limited to TNF- $\alpha$-induced signaling, additional immunoprecipitation kinase assays were performed using the PMA + ionomycin stimulus to treat cells. In agreement with the results for TNF- $\alpha$ stimulation, PG27 also showed preferential suppression of PMA + ionomycin-induced IKK $\alpha$ activity (Figure 3C). The PG27-mediated differential suppression of TNF- $\alpha$-induced IKK $\alpha$ and IKK $\beta$ activities was statistically analyzed and the results suggested that PG27, at concentrations from 25 to $200 \mathrm{ng} / \mathrm{mL}$, effectively 


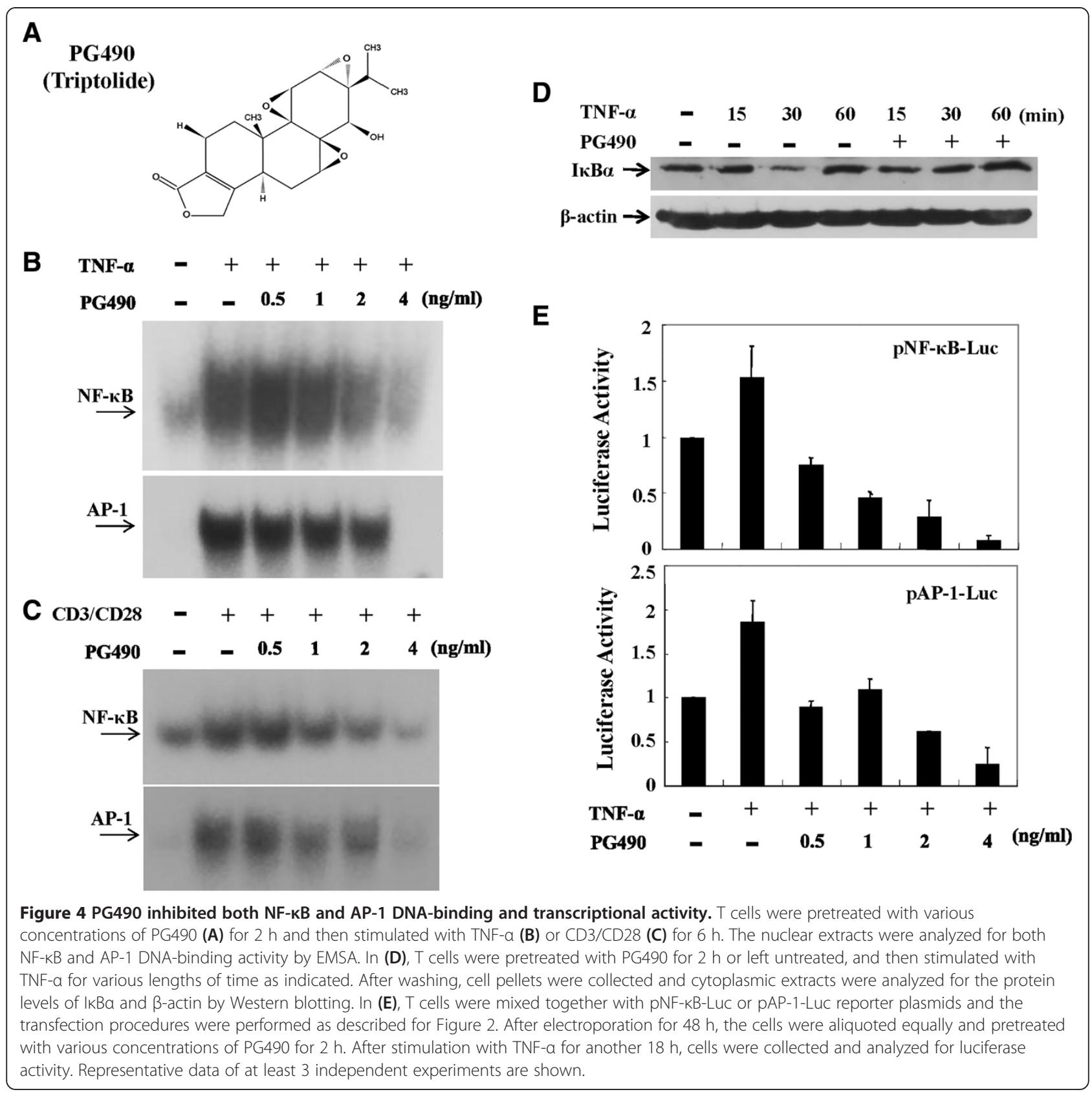

inhibited TNF- $\alpha$-induced IKK $\alpha$ activity; however, the suppression of IKK $\beta$ activity was observed only mildly under the highest PG27 concentration (Figure 3D).

\section{PG490 inhibited NF-KB and AP-1 activation}

The unexpected differential effects of PG27 on IKK activity led us to investigate the effects of the purified TwHf component, PG490 (Figure 4A). T cells were treated with various concentrations of PG490 and then stimulated with TNF- $\alpha$. Nuclear extracts were then prepared and the DNA-binding activities of NF- $\mathrm{kB}$ and AP-1 was analyzed by EMSA. As shown in Figure 4B,
PG490 reduced the TNF- $\alpha$-induced DNA-binding activities of both NF-kB and AP-1. Similar suppressive effects of PG490 were observed when the stimulus TNF- $\alpha$ was replaced by CD3/CD28 (Figure 4C). We also wanted to determine whether PG490 was able to regulate the expression of $\mathrm{I} \kappa \mathrm{B} \alpha$, which controls $\mathrm{NF}-\mathrm{kB}$ activation. Western blots indicated that PG490 effectively inhibited the degradation of IkB $\alpha$ induced by TNF$\alpha$ (Figure 4D). Consistent with these data, transfection assays demonstrated the suppressive potency of PG490 on the transcriptional activity of $\mathrm{NF}-\mathrm{kB}$ and $\mathrm{AP}-1$ (Figure 4E) induced by TNF- $\alpha$. 


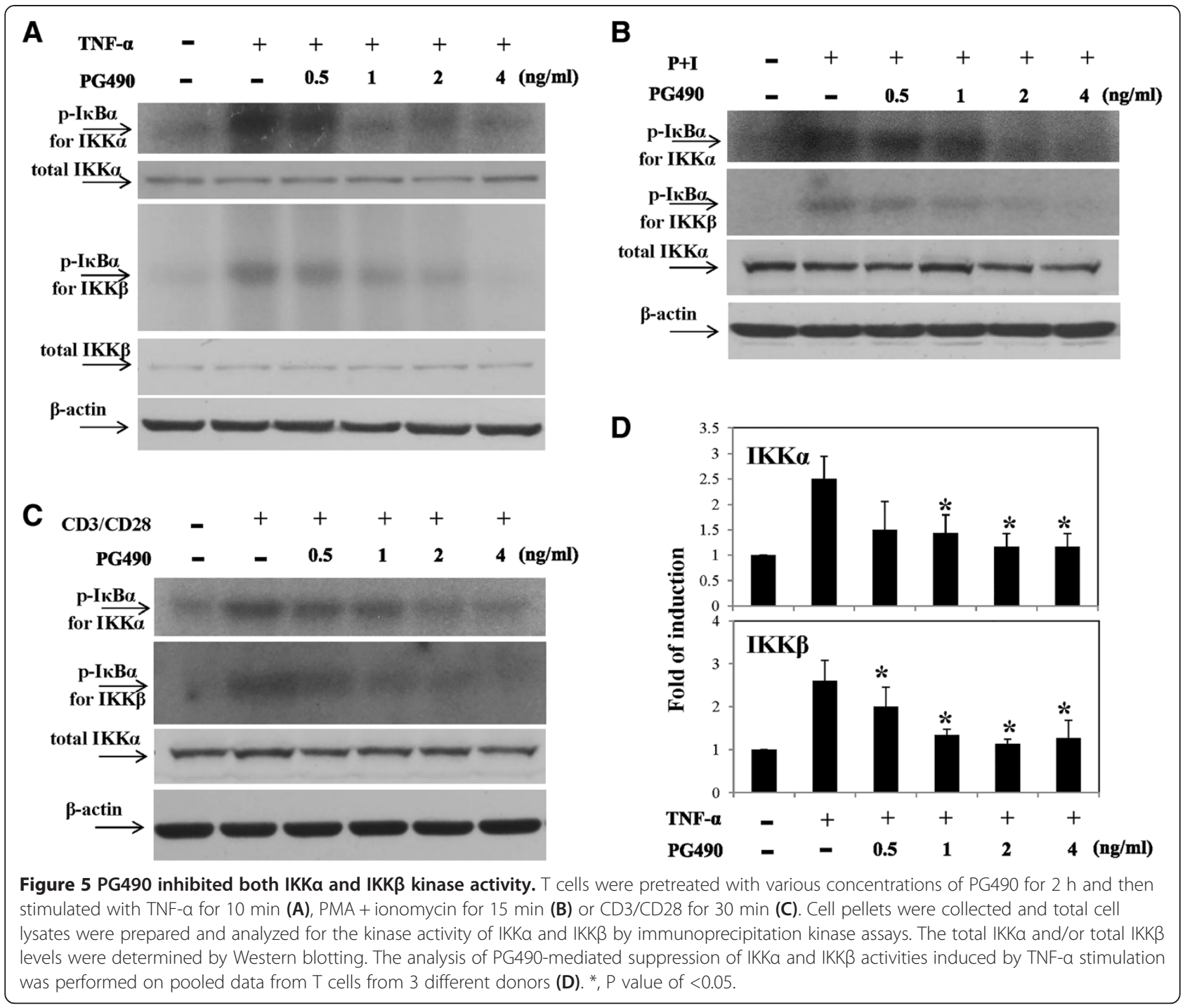

PG490 inhibited both IKKa and IKK $\beta$ activities

To determine whether PG490 was similar to PG27 in its inhibitory effects on TNF- $\alpha$-induced IKK $\alpha$ and IKK $\beta$, immunoprecipitation kinase assays were performed. Surprisingly, unlike PG27, PG490 reduced the kinase activities of both IKK $\alpha$ and IKK $\beta$ to a similar extent (Figure 5A). To investigate whether the effects of PG490 were observed only in $\mathrm{T}$ cells stimulated by TNF- $\alpha$, different $\mathrm{T}$ cell stimuli were also examined. Consistent with the observations in TNF- $\alpha$-stimulated cells, the kinase activities of both IKK $\alpha$ and IKK $\beta$ induced by PMA + ionomycin (Figure $5 \mathrm{~B}$ ) or CD3/CD28 (Figure $5 \mathrm{C}$ ) was comparably inhibited by PG490 in a concentration-dependent manner. These results indicated that the suppression of both IKK $\alpha$ and IKK $\beta$ by PG490 was generally observed in human peripheral blood $\mathrm{T}$ cells activated by different stimuli. For consistency, the PG490-mediated suppression of IKK $\alpha$ and IKK $\beta$ activities induced by TNF- $\alpha$ stimulation in T cells from 3 different donor blood was quantitatively measured (Figure 5D).

\section{PG27 and PG490 downregulated MAPK activity}

Although both PG27 and PG490 could successfully inhibit activation of NF- $\mathrm{kB}$, they preserved differential suppressive activity against NF- $\mathrm{KB}$ upstream signaling molecules IKK $\alpha$ and IKK $\beta$. Given that PG27 and PG490 could also effectively inhibit AP-1 activity, we determined whether they might have different suppressive potency on AP-1 upstream signaling kinases. Interestingly, as comparisons, the results showed that both PG27 and PG490 could effectively suppress MAP kinases, including JNK, p38 and ERK activities induced by various stimuli, albeit to different degrees (Figure 6A,B,C and D). 


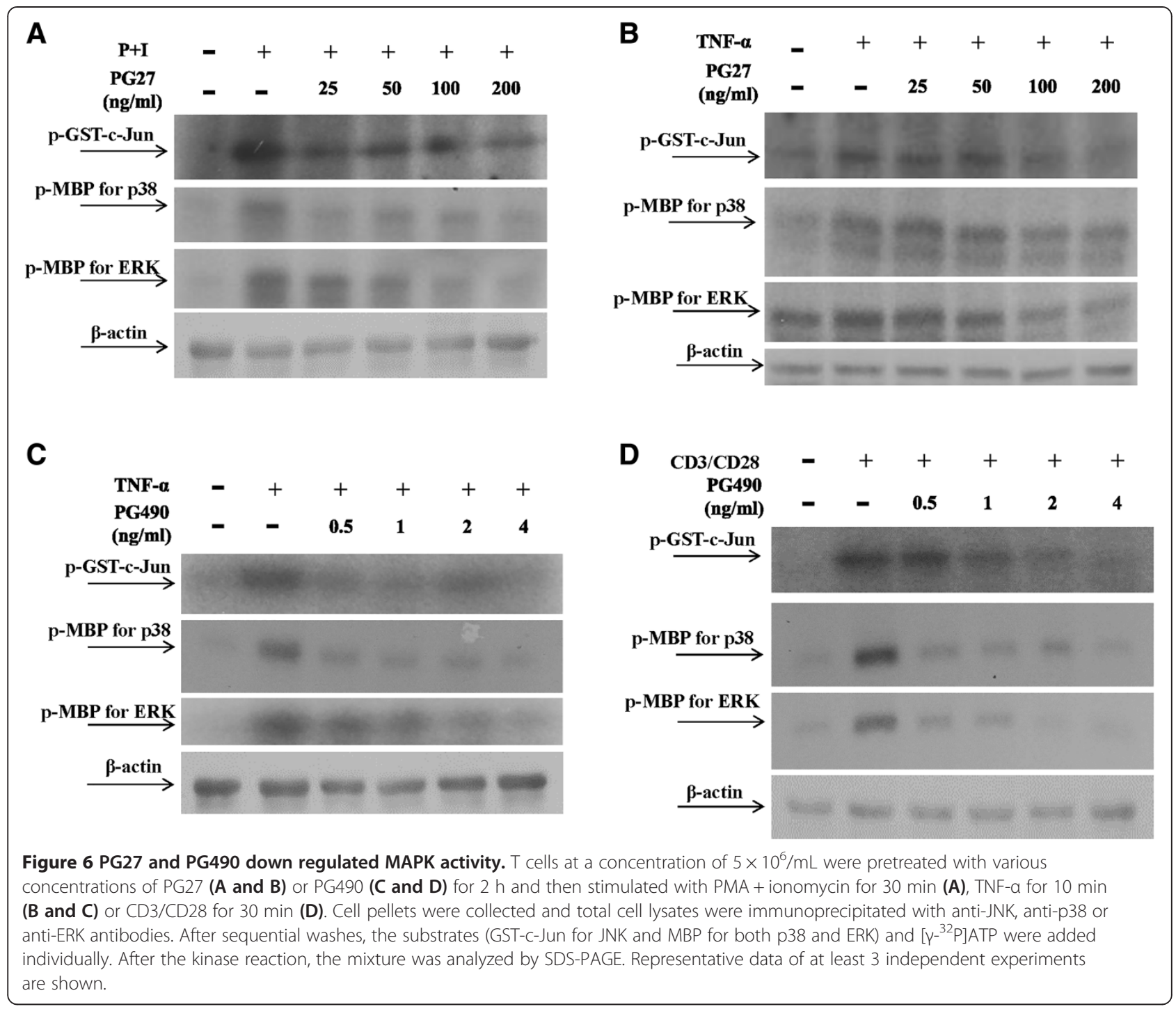

Side-by-side comparisons of the effects of PG27 and PG490 on IL-2 production and cytotoxicity in activated T cells Since IKK $\beta$ activity appeared to have differential susceptibility to inhibition by PG27 and PG490, we took further steps to determine whether PG490 was a component of PG27, and if so, how much of PG27 content was constituted by PG490. We applied HPLC to examine the contents of PG27 and to determine the percentage of PG490 in PG27. As shown in Figure 7, PG490 was estimated to constitute $1.27 \pm 0.06 \%$ of PG27, indicating that the highest concentration of PG27 used in this study (200 ng/mL) contained approximately $2.5 \mathrm{ng} / \mathrm{mL}$ of PG490. This quantity of PG490 was likely responsible in part for the PG27-mediated inhibitory effects on the IKK-NF-kB and MAPK-AP-1 signaling pathways. We subsequently examined whether the presence of other non-PG490 components in PG27 may affect the immunosuppressive potency and cytotoxic effects of PG490. T cells were pretreated in parallel with serial dilutions of PG490 or PG27 that contained an equivalent amount of PG490, and then stimulated with PMA + ionomycin. The concentrations of IL-2 in the culture supernatants were measured. The results revealed that the 50\% inhibitory concentrations $\left(\mathrm{IC}_{50}\right)$ for PG27 and PG490 on PMA + ionomycin-induced IL-2 production were $39.18 \mathrm{ng} / \mathrm{mL}$ and $0.19 \mathrm{ng} / \mathrm{mL}$, respectively (Figure $8 \mathrm{~A}$ ). The $\mathrm{IC}_{50}$ concentrations for PG27 and PG490 on CD3/CD28induced IL-2 production were $39.67 \mathrm{ng} / \mathrm{mL}$ and 0.23 $\mathrm{ng} / \mathrm{mL}$, respectively (Additional file 1: Figure S1). These data suggest that the low level of IKK $\beta$-suppressive activity in PG27 did result in a partial reduction of its immunosuppressive potency, since PG490, which was shown to suppress both IKK $\alpha$ and $I K K \beta$, had a greater inhibitory effect on IL-2 production. We then determined whether the cytotoxic effects of PG490 might be augmented or alleviated by other non-PG490 


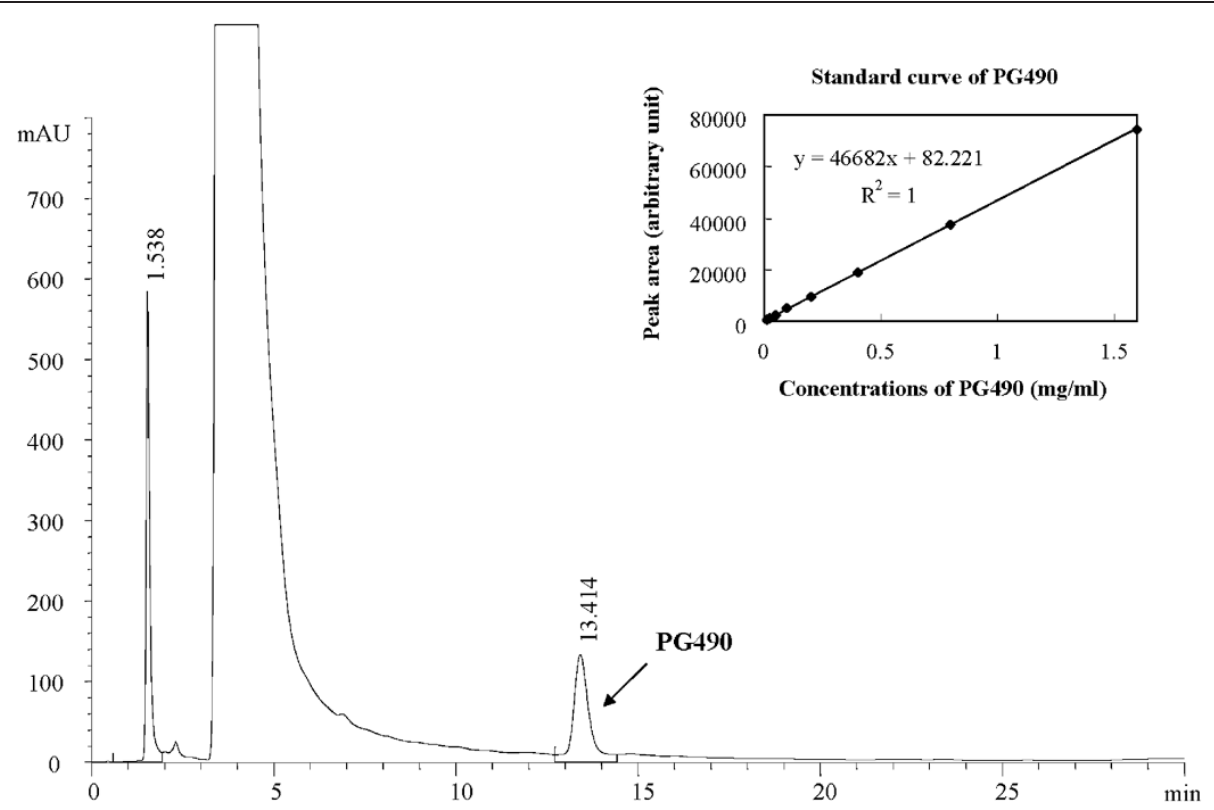

Figure 7 HPLC analysis of the quantity of PG490 in PG27. The chromatogram of PG27 with PG490 is presented, showing the retention time of $13.4 \mathrm{~min}$. PG490 calibration graphs were constructed in the range of $12.5 \mu \mathrm{g} / \mathrm{mL}$ to $1.6 \mathrm{mg} / \mathrm{mL}$. The regression equations of these curves and their correlation coefficients were calculated to be $y=46682 x+82.221\left(r^{2}=1\right.$, top-right corner). The peak area ratios show a linear relationship with the concentration of PG490. When the sample solution was analyzed by HPLC, the PG490 peak was confirmed by comparison to the retention time standards. The PG490 content in PG27 was determined to be $1.27 \pm 0.06 \%$.

components of PG27. T cells were pretreated in parallel with DMSO (the solvent), PG490 or PG27 that contained an equivalent amount of PG490, and then stimulated with PMA + ionomycin, CD3/CD28 or TNF- $\alpha$. The cell survival rate was determined by MTT colorimetric assays. As shown in Figure 8B, the 50\% lethal concentration $\left(\mathrm{LC}_{50}\right)$ of PG27 was higher than that of PG490 alone, indicating that the non-PG490 components of PG27 might have provided partial protection against PG490-induced cytotoxicity. The $\mathrm{LC}_{50}$ concentrations for PG27 and PG490 in PMA + ionomycinstimulated T cells were $689.83 \mathrm{ng} / \mathrm{mL}$ and $4.49 \mathrm{ng} / \mathrm{mL}$, respectively; in CD3/CD28-stimulated T cells, they were $943.8 \mathrm{ng} / \mathrm{mL}$ and $4.91 \mathrm{ng} / \mathrm{mL}$, respectively; and in TNF$\alpha$-stimulated T cells, they were $1913.1 \mathrm{ng} / \mathrm{mL}$ and 13.9 $\mathrm{ng} / \mathrm{mL}$, respectively (Figure $8 \mathrm{~B}$ ). The higher $\mathrm{LC}_{50}$ concentrations in TNF- $\alpha$-stimulated T cells might be due to the potential cytotoxic effects of TNF- $\alpha$, which did not occur with PMA + ionomycin and CD3/CD28-stimulated T cells.

\section{Discussion}

PG27 attracts the attention of scientists since one decade ago with its promising immunomodulatory effects in inducing antigen-specific tolerance in bone marrow transplanted mice [12] and the extending survival of cardiac xenograft models [13]. The following work was postponed because of consideration of the priority of clinical trials by the pharmaceutical company. In considering the potential applications of PG27 for autoimmune disorders, in the present study, we conducted molecular experiments to examine the mechanisms of PG27-mediated immunomodulation in human peripheral blood T cells. PG27, at therapeutic concentrations, not only suppressed various stimuli-induced transcription factor DNA-binding activities but also suppressed the transcriptional activities of both NF-kB and AP-1 (Figure 2). To our surprise, PG27 differentially regulated IKK $\alpha$ and $I K K \beta$ kinase activities induced by various stimuli. In contrast, the purified TwHf component PG490 inhibited both IKK $\alpha$ and IKK $\beta$ activities with similar potency. HPLC analysis determined that PG490 constituted $1.27 \pm 0.06 \%$ of PG27 content (Figure 7 ). Compared to PG490 alone, PG27 that contained an equal amount of PG490 was not only less potent in immunosuppressive activity but also less cytotoxic in activated T cells (Figure 8).

Based upon the "Junn-Chenn-Zuou-SS" theory, the evidence for PG490 working as "Junn", the main active ingredient, can be supported by its apoptosis-inducing effects and potent immunosuppressive effects demonstrated in a variety of tissue cells stimulated by different stimuli as well as in animal models of autoimmune disorders [11,14,22,23]. In addition to PG490, there are many uncharacterized components in PG27 and compared to PG490 alone, PG27 was less toxic. It seems probable that the IKK $\beta$-suppressive effect of PG490 was masked or neutralized by other nonPG490 components in PG27, resulting in the reduction of 

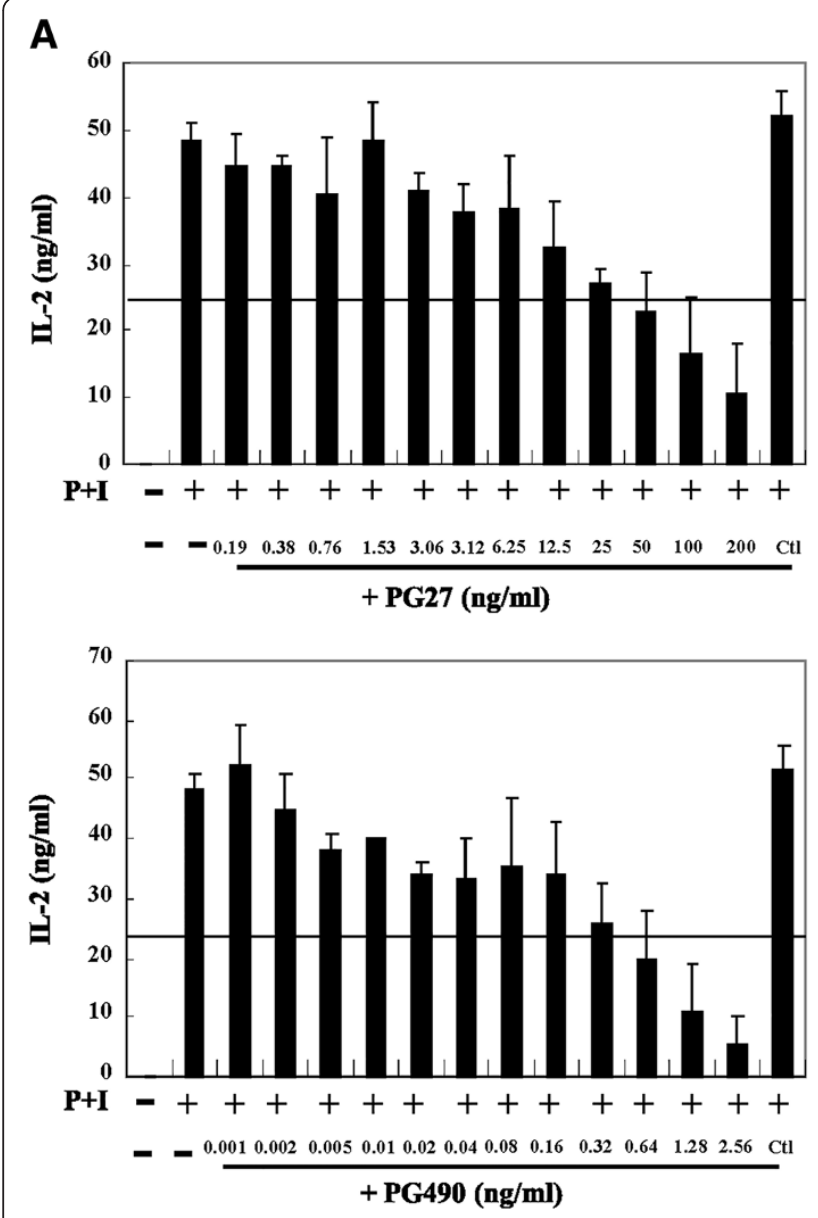
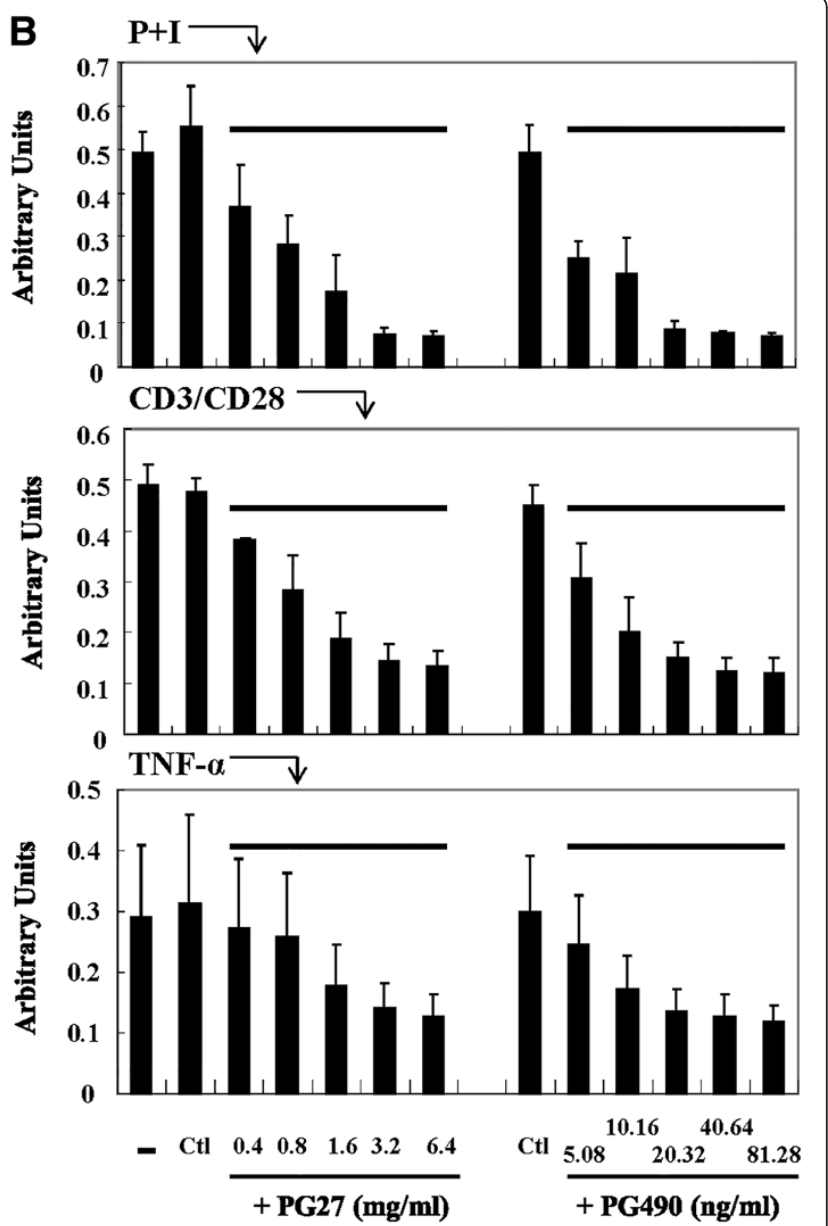

Figure 8 Side-by-side comparisons of PG27 and PG490 for immunosuppressive potency and drug cytotoxicity. T cells from a single donor were pretreated in parallel with DMSO (Ctl) or various concentrations (in serial dilutions) of PG490 or PG27 that contained an equal amount of PG490, and then stimulated with PMA + ionomycin (A) or 3 different stimuli (PMA + ionomycin, CD3/CD28 and TNF-a) as indicated (B) for $24 \mathrm{~h}$. In (A), the concentrations of PG27 and PG490 at 1× (the highest concentration) were $200 \mathrm{ng} / \mathrm{mL}$ and $2.56 \mathrm{ng} / \mathrm{mL}$, respectively. In (B), the concentrations of PG27 and PG490 at $1 \times$ (the highest concentration) were $6400 \mathrm{ng} / \mathrm{mL}$ and $81.28 \mathrm{ng} / \mathrm{mL}$, respectively. The supernatants were collected for the measurement of IL-2 (A) and the cells were collected for the measurement of cytotoxicity by MTT colorimetric assays (B). The results are representative of $\mathrm{T}$ cells from at least 3 different donors.

both immunosuppressive potency and cytotoxic effects. Accordingly, some of these non-PG490 components may function as "Zuou". Because there have been no reports simultaneously examining the combinatorial effects of two or more than two different components of TwHf, the components in PG27 that work as "Zuou" are currently unclear. Further purification and examination of PG27 components can help solve the question.

Because NF- $\kappa B$ transcription factors can up-regulate many genes involved in inflammatory responses, targeting NF- $\mathrm{kB}$ signaling events has been one of the major therapeutic goals in preventing graft rejections and in controlling autoimmune diseases $[24,25]$. The commonly prescribed disease modifying antirheumatic drugs also preserve inhibitory effects against NF-kB activation [26,27]. Regarding the significance of NF- $\mathrm{kB}$ in transplantation immunology, the

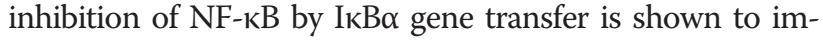
prove oxygenation of the transplanted lung [28]. Transfection with NF-kB decoy into the donor lung effectively reduces lung injury during acute allograft rejections [29]. Like NF-кB, MAPK-AP-1 signaling pathway is also a critical and excellent target to block in developing therapy for inflammation-related disorders [30,31]. The inhibition of IKK $\alpha-\mathrm{I \kappa B} \alpha-\mathrm{NF}-\mathrm{kB}$ and MAPK-AP-1 signaling pathways by PG27 and PG490 should lead them to potential candidates of promising immunomodulatory drugs for the therapy of autoimmune disorders and for the prevention of graft rejections.

Three major classes of stimuli, including PMA + ionomycin, the CD28 costimulatory molecule, and TNF- $\alpha$, were used to activate T cells for the investigation of the immunomodulatory effects of PG27 and PG490 in human 
peripheral blood T cells. Different types of stimuli did not seem to affect the experimental outcomes, as the results were consistent and reproducible regardless of the stimuli being evaluated. PMA + ionomycin mimics a $\mathrm{T}$ cell receptor-mediated stimulus that bypasses the requirement for an antigen- or lectin-induced signal [32]. The proinflammatory cytokine, TNF- $\alpha$, is considered to be an important molecule for the regulation of upstream cytokine cascades in inflammatory responses. The blockade of TNF$\alpha$-mediated events has been found to have significant therapeutic effects on active RA and seronegative spondyloarthropathies [33]. Given the significance of CD28 signaling in $\mathrm{T}$ cell activation, blockade of the CD28 signaling pathway is another promising therapeutic strategy for RA, even for those who are refractory to anti-TNF therapy [34]. Considering the critical roles of $\mathrm{T}$ cells in autoimmune disorders, we examined these crucial stimuli-activated $\mathrm{T}$ cells and demonstrated the broad-spectrum immunosuppressive capacities of both PG27 and PG490.

The differential inhibitory potency of PG27 against $I K K \alpha$ and $I K K \beta$ is interesting. Studies of many different compounds against IKK activity have indicated that for arthritis therapeutics, the suppression of either IKK $\alpha$ or IKK $\beta$ may be sufficient to block NF- $\kappa B$ activation [35]. The concentrations of $\mathrm{IC}_{50}$ for PG490 and PG27 with equivalent content of PG490 on PMA + ionomycin-induced and CD3/CD28-induced IL-2 production indicate that PG490 preserved more potent immunosuppressive activity than PG27. It suggests that the counteraction of PG490-mediated IKK $\beta$ suppression by other components resulted in reduction of immunosuppressive potency of PG27. Nevertheless, the selective suppression of IKK $\alpha$ but not IKK $\beta$ by PG27 may potentially lead to some benefits therapeutically. For example, in knockout studies, the targeted deletion of IKK $\beta$ results in early embryonic lethality due to extensive apoptosis of fetal hepatocytes $[36,37]$. In contrast, the deficiency of IKK $\alpha$ which results in abnormal development of skin and skeleton is relatively less fatal [38]. In addition, IKK $\beta$ plays a requisite role in B cell activation and maintenance [39]. Furthermore, the preservation of intact $I K K \beta-N F-k B$ signaling pathway is important for protecting $\mathrm{T}$ cells from TNF- $\alpha-$ induced apoptosis [38]. According to Egan et al. [40], in an in vivo system, the preservation of IKK $\beta$ dependent NF- $\mathrm{KB}$ activation pathway is crucial for protection against radiation-induced apoptosis in intestinal epithelium. It is therefore possible that given an already suppressed IKK $\alpha-N F-\kappa B$ signaling pathway, the preservation of $\mathrm{IKK} \beta-\mathrm{NF}-\mathrm{kB}$ signaling pathway may help to reduce the potential side effects of PG27 in T cells and in other tissue cells. This suggestion was supported by a much reduced cytotoxic effect, as compared to PG490 alone, in PG27 containing equivalent amount of PG490 content.

\section{Conclusions}

In this study, we observed that PG27 and PG490 had differential suppressive effects on IKK $\alpha$ and IKK $\beta$ activities induced by a variety of stimuli in T cells. The results also suggest that compared to PG490 alone, PG27 that contained an equivalent amount of PG490 caused less cell death. In light of the current therapeutic strategy for autoimmune disorders, which involves the combination of several disease-modifying antirheumatic drugs to increase efficacy and reduce adverse events [1], the exploration of the effects and mechanisms of Chinese antirheumatic drugs such as PG27 should provide additional alternatives for the therapy of autoimmune disorders like RA.

There are several limitations in this report. Firstly, it remains unclear the components responsible for counteracting PG490-mediated IKK $\beta$-suppressive effects. Secondly, this in vitro study can not exactly reflect the in vivo situations, especially the situations in humans. Thirdly, whether the observations in T cells may happen in other tissue cells requires additional experiments to examine. Lastly, only a head-to-head comparison in clinical trials but not in this study can really tell us whether the observed benefit/risk of PG27 compared to PG490 does exist. Evidently, more studies are needed to answer these questions.

Traditional Chinese medicine prescriptions "Fufang" usually contain several herbs (each called "Danfang"). The traditional Chinese medicinal doctors will modify and adjust the ingredients and doses of each "Danfang" according to the need of individual patients. This formulation is based on the principle of "Junn-Chenn-Zuou-SS". Therefore, the commonly accepted working concept of "Junn-ChennZuou-SS" illustrates the specific coordinated effects from a combination of different Chinese herbs. In this study, we provide novel and interesting observations demonstrating that the "Junn-Chenn-Zuou-SS" theory may also work in a refined extract PG27 from a single herb TwHf. It is anticipated that with the inclusion of more molecular studies on Chinese herbs, the concept of "Junn-Chenn-Zuou-SS" will gain more scientific support.

\section{Additional file}

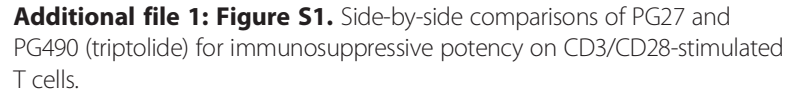

Additional file 1: Figure S1. Side-by-side comparisons of PG27 and PG490 (triptolide) for immunosuppressive potency on CD3/CD28-stimulated T cells.

Competing interests

The authors declare that they have no competing interests.

\section{Authors' contributions}

LJH designed the study, performed most of the experiments of this study, and wrote the manuscript. JHL and $\mathrm{LJH}$ critically correct the manuscript, gave advice and guided experimental steps along the experimental process and take responsibility for correctness of the study results. WLC, AC and PC helped to perform part of the experiments and review the manuscript. All authors read and approved the final manuscript. 


\section{Acknowledgements}

This work is supported in part by grants from the National Health Research Institutes (NHRI-EX94-9208SI), the Department of Health (CCMP92-RD-112) and the National Science Council (NSC 101-2314-B-182A-103-MY3), Taipei, Taiwan, R.O.C. The kind gift from Dr. S.F. Yang is greatly appreciated.

\section{Author details}

'Institute of Cellular and System Medicine, National Health Research Institute, Zhunan, Taiwan, R. O. C. ${ }^{2}$ Graduate Institute of Basic Medical Science, PhD Program of Aging, China Medical University, Taichung, Taiwan, R. O. C. ${ }^{3}$ School of Pharmacy, National Defense Medical Center, Taipei, Taiwan, R. O. C. ${ }^{4}$ Department of Pathology, National Defense Medical Center, Taipei, Taiwan, R.O.C. ${ }^{5}$ Institute of Molecular Biology, Academia Sinica, Taipei, R. O. C. ${ }^{6}$ Division of Allergy, Immunology and Rheumatology, Department of Internal Medicine, Chang Gung Memorial Hospital, Chang Gung University, Tao-Yuan, Taiwan, R. O. C.

Received: 28 July 2013 Accepted: 19 November 2013

Published: 21 November 2013

\section{References}

1. O'Dell JR, Mikuls TR, Taylor TH, Ahluwalia V, Brophy M, Warren SR, Lew RA, Cannella AC, Kunkel G, Phibbs CS, et al: Therapies for active rheumatoid arthritis after methotrexate failure. N Engl J Med 2013, 369:307-318.

2. Sharma PL, Nurpeisov V, Hernandez-Santiago B, Beltran T, Schinazi RF: Nucleoside inhibitors of human immunodeficiency virus type 1 reverse transcriptase. Curr Top Med Chem 2004, 4:895-919.

3. Ho L, Lai JH: Chinese herbs as immunomodulators and potential disease-modifying antirheumatic drugs in autoimmune disorders. Curr Drug Metab 2004, 5:181-192.

4. Cameron M, Gagnier JJ, Chrubasik S: Herbal therapy for treating rheumatoid arthritis. Cochrane Database Syst Rev 2011:CD002948.

5. Tao X, Younger J, Fan FZ, Wang B, Lipsky PE: Benefit of an extract of tripterygium wilfordii hook $\mathrm{F}$ in patients with rheumatoid arthritis: a double-blind, placebo-controlled study. Arthritis Rheum 2002, 46:1735-1743.

6. Goldbach-Mansky R, Wilson M, Fleischmann R, Olsen N, Silverfield J, Kempf P, Kivitz A, Sherrer Y, Pucino F, Csako G, et al: Comparison of tripterygium wilfordii hook $F$ versus sulfasalazine in the treatment of rheumatoid arthritis: a randomized trial. Ann Intern Med 2009, 151:229-240. W249-251.

7. Ho LJ, Chang DM, Chang ML, Kuo SY, Lai JH: Mechanism of immunosuppression of the antirheumatic herb TWHf in human T cells. J Rheumatol 1999, 26:14-24.

8. Lai JH, Ho L, Lu KC, Chang DM, Shaio MF, Han SH: Western and Chinese antirheumatic drug-induced T cell apoptotic DNA damage uses different caspase cascades and is independent of Fas/Fas ligand interaction. J Immunol 2001, 166:6914-6924.

9. Kupchan SM, Court WA, Dailey RG Jr, Gilmore CJ, Bryan RF: Triptolide and tripdiolide, novel antileukemic diterpenoid triepoxides from Tripterygium wilfordii. J Am Chem Soc 1972, 94:7194-7195.

10. Tao X, Cai JJ, Lipsky PE: The identity of immunosuppressive components of the ethyl acetate extract and chloroform methanol extract (T2) of Tripterygium wilfordii Hook F. J Pharmacol Exp Therl 1995, 272:1305-1312.

11. Zhou ZL, Yang YX, Ding J, Li YC, Miao ZH: Triptolide: structural modifications, structure-activity relationships, bioactivities, clinical development and mechanisms. Nat Prod Rep 2012, 29:457-475.

12. Chen Y, Zeng D, Schlegel PG, Fidler J, Chao NJ: PG27, an extract of Tripterygium wilfordii hook $\mathrm{f}$, induces antigen-specific tolerance in bone marrow transplantation in mice. Blood 2000, 95:705-710.

13. Wang J, Xu R, Jin R, Chen Z, Fidler JM: Immunosuppressive activity of the Chinese medicinal plant Tripterygium wilfordii. II. Prolongation of hamster-to-rat cardiac xenograft survival by combination therapy with the PG27 extract and cyclosporine. Transplantation 2000, 70:456-464.

14. Han R, Rostami-Yazdi M, Gerdes S, Mrowietz U: Triptolide in the treatment of psoriasis and other immune-mediated inflammatory diseases. $\mathrm{Br} J \mathrm{Clin}$ Pharmacol 2012, 74:424-436

15. Zhang Y, Ma X: Triptolide inhibits IL-12/IL-23 expression in APCs via CCAAT/enhancer-binding protein alpha. J Immunol 2010, 184:3866-3877.
16. Ruland J: Return to homeostasis: downregulation of NF-kappaB responses. Nat Immunol 2011, 12:709-714.

17. Hinz M, Arslan SC, Scheidereit C: It takes two to tango: IkappaBs, the multifunctional partners of NF-kappaB. Immunol Rev 2012 246:59-76

18. Kanarek N, Ben-Neriah Y: Regulation of NF-kappaB by ubiquitination and degradation of the IkappaBs. Immunol Rev 2012, 246:77-94.

19. Criswell LA: Gene discovery in rheumatoid arthritis highlights the CD40/ NF-kappaB signaling pathway in disease pathogenesis. Immunol Rev 2010, 233:55-61.

20. Schonthaler HB, Guinea-Viniegra J, Wagner EF: Targeting inflammation by modulating the Jun/AP-1 pathway. Ann Rheum Dis 2011, 70(Suppl 1):i109-i112.

21. Yang SP, Ho LI, Lin YL, Cheng SM, Tsao TP, Chang DM, Hsu YL, Shih CY, Juan TY, Lai JH: Carvedilol, a new antioxidative beta-blocker, blocks in vitro human peripheral blood T cell activation by downregulating NF-kappaB activity. Cardiovasc Res 2003, 59:776-787.

22. Choi YJ, Kim TG, Kim YH, Lee SH, Kwon YK, Suh SI, Park JW, Kwon TK: Immunosuppressant PG490 (triptolide) induces apoptosis through the activation of caspase-3 and down-regulation of XIAP in U937 cells. Biochem Pharmacol 2003, 66:273-280.

23. Liu J, Jiang Z, Xiao J, Zhang Y, Lin S, Duan W, Yao J, Liu C, Huang X, Wang T, et al: Effects of triptolide from Tripterygium wilfordii on ERalpha and p53 expression in two human breast cancer cell lines. Phytomedicine 2009, 16:1006-1013.

24. Karin M, Yamamoto Y, Wang QM: The IKK NF-kappa B system: a treasure trove for drug development. Nat Rev Drug Discov 2004, 3:17-26.

25. Ruan $\mathrm{Q}$, Chen YH: Nuclear factor-kappaB in immunity and inflammation: the Treg and Th17 connection. Adv Exp Med Biol 2012, 946:207-221.

26. Majumdar S, Aggarwal BB: Methotrexate suppresses NF-kappaB activation through inhibition of IkappaBalpha phosphorylation and degradation. J Immunol 2001, 167:2911-2920.

27. Manna SK, Mukhopadhyay A, Aggarwal BB: Leflunomide suppresses TNF-induced cellular responses: effects on NF-kappa B, activator protein-1, c-Jun N-terminal protein kinase, and apoptosis. J Immunol 2000, 165:5962-5969.

28. Ishiyama T, Dharmarajan S, Hayama M, Moriya H, Grapperhaus K, Patterson GA: Inhibition of nuclear factor kappaB by lkappaB superrepressor gene transfer ameliorates ischemia-reperfusion injury after experimental lung transplantation. J Thorac Cardiovasc Surg 2005, 130:194-201.

29. Ohmori K, Takeda S, Miyoshi S, Minami M, Nakane S, Ohta M, Sawa Y, Matsuda $\mathrm{H}$ : Attenuation of lung injury in allograft rejection using NF-kappaB decoy transfection-novel strategy for use in lung transplantation. Eur J Cardiothorac Surg 2005, 27:23-27.

30. Manning AM, Davis RJ: Targeting JNK for therapeutic benefit: from junk to gold? Nat Rev Drug Discov 2003, 2:554-565.

31. Sakurai H: Targeting of TAK1 in inflammatory disorders and cancer. Trends Pharmacol Sci 2012, 33:522-530.

32. Truneh A, Albert F, Golstein P, Schmitt-Verhulst AM: Early steps of lymphocyte activation bypassed by synergy between calcium ionophores and phorbol ester. Nature 1985, 313:318-320

33. Thalayasingam N, Isaacs JD: Anti-TNF therapy. Best Pract Res Clin Rheumatol 2011, 25:549-567.

34. Furst DE, Keystone EC, Braun J, Breedveld FC, Burmester GR, De Benedetti F, Dorner T, Emery P, Fleischmann R, Gibofsky A, et al: Updated consensus statement on biological agents for the treatment of rheumatic diseases, 2011. Ann Rheum Dis 2012, 71(Suppl 2):i2-i45.

35. Suzuki J, Ogawa M, Muto S, Itai A, Isobe M, Hirata Y, Nagai R: Novel IkB kinase inhibitors for treatment of nuclear factor-kB-related diseases. Expert Opin Investig Drugs 2011, 20:395-405.

36. Li ZW, Chu W, Hu Y, Delhase M, Deerinck T, Ellisman M, Johnson R, Karin M: The IKKbeta subunit of IkappaB kinase (IKK) is essential for nuclear factor kappaB activation and prevention of apoptosis. J Exp Med 1999, 189:1839-1845.

37. Tanaka M, Fuentes ME, Yamaguchi K, Durnin MH, Dalrymple SA, Hardy KL, Goeddel DV: Embryonic lethality, liver degeneration, and impaired NF-kappa B activation in IKK-beta-deficient mice. Immunity 1999, 10:421-429.

38. Li Q Lu Q Hwang JY, Buscher D, Lee KF, Izpisua-Belmonte JC, Verma IM: IKK1-deficient mice exhibit abnormal development of skin and skeleton. Genes Dev 1999, 13:1322-1328. 
39. Li ZW, Omori SA, Labuda T, Karin M, Rickert RC: IKK beta is required for peripheral B cell survival and proliferation. J Immunol 2003, 170:4630-4637.

40. Egan L, Eckmann L, Greten FR, Chae S, Li ZW, Myhre GM, Robine S, Karin M, Kagnoff MF: IkappaB-kinasebeta-dependent NF-kappaB activation provides radioprotection to the intestinal epithelium. Proc Natl Acad SCi USA 2004, 101:2452-2457.

doi:10.1186/1479-5876-11-294

Cite this article as: Ho et al: Differential immunomodulatory effects by Tripterygium wilfordii Hook f-derived refined extract PG27 and its purified component PG490 (triptolide) in human peripheral blood T cells: potential therapeutics for arthritis and possible mechanisms explaining in part Chinese herbal theory "Junn-Chenn-Zuou-SS". Journal of Translational Medicine 2013 11:294.

\section{Submit your next manuscript to BioMed Central and take full advantage of:}

- Convenient online submission

- Thorough peer review

- No space constraints or color figure charges

- Immediate publication on acceptance

- Inclusion in PubMed, CAS, Scopus and Google Scholar

- Research which is freely available for redistribution 